\title{
Corrigendum
}

\section{A note on heat shock protein 70 expression in goats subjected to road transportation under hot, humid tropical conditions - CORRIGENDUM}

\author{
I. Zulkifli, B. Norbaiyah, Y. W. Cheah, A. F. Soleimani, A. Q. Sazili, Y. M. Goh and M. A. Rajion
}

(First published online 21 May 2010)

doi:10.1017/S1751731110000285, published by Cambridge University Press, 26 February 2010

Unfortunately, a heading in the above paper was published incorrectly. The heading Brain samples on page 2 should read: Heart and kidney samples. The authors would like to apologise for this error.

\section{Reference}

Zulkifli I, Norbaiyah B, Cheah YW, Soleimani AF, Sazili AQ, Goh YM and Rajion MA 2010. A note on heat shock protein 70 expression in goats subjected to road transportation under hot, humid tropical conditions. Animal 4, 973-976; doi:10.1017/S1751731110000285. 